\title{
Videolaparoscopic appendectomy: the current outlook
}

\author{
K. H. in't Hof · G. Kazemier
}

Published online: 11 December 2007

(C) Springer Science+Business Media, LLC 2007

\section{Erratum to: Surg Endosc}

DOI: $10.1007 / \mathrm{s} 00464-007-9518-\mathrm{z}$

A coauthor, G. Kazemier, was inadvertently omitted from this article which was published in Vol. 21, No. 10, p. 1901.

Springer regrets the error.

The online version of the original article can be found under doi: 10.1007/s00464-007-9518-z.

K. H. in’t Hof $(\bowtie) \cdot$ G. Kazemier Erasmus Medical Centre, 3000, CA, Rotterdam, Netherlands e-mail: k.inthof@erasmusmc.nl 